\title{
Timing of Initial Antibiotic Treatment for Febrile Neutropenia in the Emergency Department: The Need for Evidence-Based Guidelines
}

\author{
Demetrios N. Kyriacou, MD, PhDa,b; Borko Jovanovic, $\mathrm{PhD}^{\mathrm{b}}$; and Olga Frankfurt, $\mathrm{MD}^{\mathrm{a}, \mathrm{d}}$
}

\begin{abstract}
Guidelines for the treatment of febrile neutropenia (FN) universally recommend the prompt initiation ( $<60$ minutes) of antibiotic therapy for patients with this complication presenting to medical settings. Unfortunately, administration delays exist in emergency departments where patients with FN frequently seek care. Future guidelines should be based on investigations that clearly indicate the effectiveness of rapid antibiotic therapy. If definitive investigations identify an optimal time period for the initial administration of antibiotics for patients with $\mathrm{FN}$, administrative efforts will be developed to improve the emergency department care of these critically ill patients with cancer. (J Natl Compr Canc Netw 2014;12:1569-1573)
\end{abstract}

Over the past several decades, the development of effective chemotherapeutic regimens has significantly improved the overall survival of patients with cancer. ${ }^{1-4}$ Unfortunately, many of these treatment regimens cause profound bone marrow suppression with resultant leukopenia that renders these patients susceptible to serious infections, often with fever as the only clinical finding. ${ }^{5-8}$ This complication, known as febrile neutropenia (FN), occurs in $10 \%$ to

From the a Department of Emergency Medicine, bepartment of Preventive Medicine, and 'Division of Hematology/Oncology, Northwestern University Feinberg School of Medicine, and the ${ }^{d}$ Robert H. Lurie Comprehensive Cancer Center of Northwestern University, Chicago, Illinois.

Submitted February 28, 2014; accepted for publication June 15, 2014.

The authors have disclosed that they have no financial interests, arrangements, affiliations, or commercial interests with the manufacturers of any products discussed in this article or their competitors.

Correspondence: Demetrios N. Kyriacou, MD, PhD, Northwestern University Feinberg School of Medicine, 211 Ontario Street, Suite 200, Chicago, IL 60611. E-mail: d-kyriacou@northwestern.edu
$30 \%$ of patients undergoing chemotherapy (depending on several factors) and causes significant morbidity and mortality, with important long-term implications regarding the use of health care resources. ${ }^{9-14} \mathrm{~A}$ recent national study of patients with FN treated at 115 medical centers throughout the United States estimated an in-hospital mortality rate of $9.5 \%$ with a mean hospital stay of 11.5 days. ${ }^{15}$

The modern management of FN began approximately 50 years ago when several landmark studies reported superior mortality and morbidity outcomes associated with empirical treatment with broad-spectrum antibiotics before the isolation of bacterial organisms. ${ }^{5,16-19}$ Since then, extensive clinical and research efforts have focused on developing the most effective antibiotic treatment regimens for patients with FN based on individual risk stratification and identification of the causative infectious organism. ${ }^{20-22}$ These efforts have also prompted the development of guidelines by various national and international organizations to maximize the treatment of chemotherapy-induced FN in adult patients across institutions and countries (Table 1). ${ }^{22-30}$ A universally accepted feature of empiric treatment is the prompt initiation of antibiotic therapy at the earliest possible time (within 30-60 minutes) in patients presenting with $\mathrm{FN}$ to a medical setting.

Because rapid assessment and initial antibiotic treatment of FN are considered critical, patients with cancer who have this complication are frequently evaluated and managed in the emergency department (ED) before hospitalization. ${ }^{31-38}$ However, despite recommendations for rapid initial antibiotic treatment of patients with $\mathrm{FN}$, significant delays in administration still occur in this setting. ${ }^{32-39}$ Table 2 presents several studies that illustrate the delayed times to initial antibiotic treatment for adults with FN in EDs 
Kyriacou et al

\section{Table 1 Current Guidelines for Timing of Initial Antibiotic Treatment of Adult Patients With Febrile Neutropenia}

Reference, Organization, and Region

Tam et al, 222011

Victorian Integrated Cancer Services (Australia)

Freifeld et al, ${ }^{23} 2011$

Infectious Disease Society of America

(North America)

Przybylo et al, ${ }^{24} 2011$

United Kingdom Department of Health

(United Kingdom)

National Chemotherapy Advisory Group, ${ }^{25} 2009$

(United Kingdom)

Clinical Oncology Information Network, ${ }^{26} 2008$

Royal College of Radiologists

(United Kingdom)

Marti et al,27 2009

ESMO Guidelines Working Group

(Europe)

Penack et al, ${ }^{28} 2011$

German Society of Hematology and Oncology

(Germany)

Flowers et al, 292013

ASCO

(USA)

Baden et al $^{30} 2013$

National Comprehensive Cancer Network

(USA)

worldwide, indicating poor compliance with the recommendations noted in Table 1. In fact, the mean or median time to initial antibiotics ranged from 102 to 300 minutes, far exceeding the commonly recommend time of less than 60 minutes. Even for patients with severe sepsis or septic shock, a French multicenter study found that only 19 of 89 study subjects (21\%) received initial antibiotic treatment within 90 minutes of their presentation. ${ }^{36}$

It is generally accepted that early versus delayed antibiotic treatment in the ED is beneficial for patients with severe bacterial infections. In fact, several studies have demonstrated improved outcomes with earlier ED antibiotic treatment for sepsis, meningitis, and pneumonia. ${ }^{40-51}$ In particular, Kumar et al ${ }^{41}$ found that for patients in septic shock, "time to initiation of effective antimicrobial therapy was the single strongest predictor of outcome." An important consequence of these studies has been the development of guidelines that have reduced the time to initial antibiotic treatment for patients with severe infections in the ED setting. ${ }^{52,53}$ Unfortunately, findings from these
Recommended Timing of Initial Antibiotic Treatment

First dose antibiotic: within 30 minutes if systemically compromised; 1 hour if clinically stable

All patients who present with fever and neutropenia should be treated swiftly and broadly with antibiotics to treat gram-positive and gram-negative pathogens

Department of Health guidance mandates administration of intravenous broad-spectrum antibiotics within 1 hour

All hospitals which might receive patients with acute complications of cancer should ensure delivery of antibiotics occurs within 1 hour for patients presenting with neutropenic sepsis

Intravenous antibiotics should be started within 30 minutes in $100 \%$ of patients who have received recent chemotherapy and who are shocked

Standard management of febrile neutropenia involves prompt administration of empiric broad-spectrum, intravenous antibacterial therapy with additional supportive care (eg, intravenous fluid, oxygen) as indicated

Empirical antimicrobial treatment using broad-spectrum antibiotics must be started immediately in patients with neutropenia with sepsis

Patients with febrile neutropenia should receive initial doses of empirical antibacterial therapy within an hour of triage

All patients with neutropenia should be treated empirically with broad-spectrum antibiotics promptly at the first sign of infection (ie, fever)

studies do not appear to have translated to faster initial antibiotic treatment for adult patients with $\mathrm{FN}$ in the ED setting.

Although it seems intuitive that all patients with FN should receive their initial antibiotic treatment within 60 minutes of presentation to an $\mathrm{ED}$, this goal is problematic for several clinical and administrative reasons. For example, patients must be properly evaluated with laboratory tests and radiographs to determine neutropenia and identify a possible source of infection. ${ }^{54}$ Unfortunately, broad-spectrum antibiotic administration is not without risk, and inappropriate initial empirical therapy has been associated with increased mortality and morbidity in certain patients with sepsis. ${ }^{55-58}$ Consequently, physicians are often reluctant to initiate empirical antibiotic treatment before confirming the diagnosis of neutropenia. In addition, because of the demand for emergency nurses and physicians to provide rapid care to many patients with different critical conditions, any administrative strategy aimed at reducing time to initial antibiotic treatment must be supported by 
Antibiotic Treatment for Febrile Neutropenia

\section{Table 2 Times to Initial Antibiotic Treatment for Adult Febrile Neutropenia in ED Settings}

\begin{tabular}{|c|c|c|c|c|c|c|c|}
\hline Study and Setting & $\begin{array}{l}\text { Definition } \\
\text { of Febrile } \\
\text { Neutropenia }\end{array}$ & $\begin{array}{l}\text { ED } \\
\text { Patient } \\
\text { Visits }\end{array}$ & Mean ANC & $\begin{array}{l}\text { Demographic } \\
\text { Distribution }\end{array}$ & $\begin{array}{l}\text { Received } \\
\text { Antibiotics } \\
\text { in the ED }\end{array}$ & $\begin{array}{l}\text { Overall } \\
\text { Mortality }\end{array}$ & $\begin{array}{l}\text { Time to } \\
\text { Initial } \\
\text { Antibiotic } \\
\text { Treatment }\end{array}$ \\
\hline $\begin{array}{l}\text { Perrone et al, }{ }^{32} 2004 \\
\text { Hospital of the } \\
\text { University of } \\
\text { Pennsylvania } \\
\text { (USA) }\end{array}$ & $\begin{array}{l}\text { Chemotherapy } \\
\text { Temp }>100.4^{\circ} \mathrm{F} \\
\text { ANC }<1000 / \mathrm{mm}^{3}\end{array}$ & 55 & $436 / \mathrm{mm}^{3}$ & $\begin{array}{l}\text { Mean age, } 52.0 y \\
\text { with } 53 \% \text { men }\end{array}$ & $\begin{array}{l}55 / 55 \\
(100 \%)\end{array}$ & $\begin{array}{l}2 / 55 \\
(3.6 \%)\end{array}$ & $\begin{array}{l}170 \text { min } \\
\text { (mean) }\end{array}$ \\
\hline $\begin{array}{l}\text { Nirenberg et al, }{ }^{33} 2004 \\
\text { New York - Presbyterian } \\
\text { Hospital/Columbia } \\
\text { University } \\
\text { (USA) }\end{array}$ & $\begin{array}{l}\text { Chemotherapy or } \\
\text { radiation therapy } \\
\text { Temp }>100.9^{\circ} \mathrm{F} \\
\text { ANC }<1000 / \mathrm{mm}^{3}\end{array}$ & 23 & $400 / \mathrm{mm}^{3}$ & $\begin{array}{l}\text { Mean age, } 56.0 \text { y } \\
\text { with } 53 \% \text { men }\end{array}$ & $\begin{array}{l}23 / 23 \\
(100 \%)\end{array}$ & $\begin{array}{l}0 / 23 \\
(0 \%)\end{array}$ & $\begin{array}{l}210 \text { min } \\
\text { (median) }\end{array}$ \\
\hline $\begin{array}{l}\text { Courtney et al, }{ }^{34} 2007 \\
\text { Northwestern Memorial } \\
\text { Hospital } \\
\text { (USA) }\end{array}$ & $\begin{array}{l}\text { Temp } \geq 100.4^{\circ} \mathrm{F} \\
\text { ANC } \leq 500 / \mathrm{mm}^{3}\end{array}$ & 57 & $93 / \mathrm{mm}^{3}$ & $\begin{array}{l}\text { Mean age, } 58.0 \text { y } \\
\text { with } 52 \% \text { men }\end{array}$ & $\begin{array}{l}52 / 57 \\
(91 \%)\end{array}$ & $\begin{array}{l}6 / 57 \\
(10.5 \%)\end{array}$ & $\begin{array}{l}102 \text { min } \\
\text { (median) }\end{array}$ \\
\hline $\begin{array}{l}\text { Lim et al, }{ }^{, 5} 2012 \\
\text { University of Alberta } \\
\text { Hospital } \\
\text { (Canada) }\end{array}$ & $\begin{array}{l}\text { Temp }>100.4^{\circ} \mathrm{F} \\
\text { WBC }<1000 / \mathrm{mm}^{3} \\
\text { or ANC }<500 / \mathrm{mm}^{3}\end{array}$ & 128 & $100 / \mathrm{mm}^{3}$ & $\begin{array}{l}\text { Median age, } 51.0 y \\
\text { with } 54 \% \text { men }\end{array}$ & NA & NA & $\begin{array}{l}234 \text { min } \\
\text { (median) }\end{array}$ \\
\hline $\begin{array}{l}\text { Lim et al, }{ }^{35} 2012 \\
\text { Royal Alexandra } \\
\text { Hospital, Grey Nuns } \\
\text { Community Hospital, } \\
\text { and Misericordia } \\
\text { Community Hospital } \\
\text { (Canada) }\end{array}$ & $\begin{array}{l}\text { Temp }>100.4^{\circ} \mathrm{F} \\
\text { WBC }<1000 / \mathrm{mm}^{3} \\
\text { or ANC }<500 / \mathrm{mm}^{3}\end{array}$ & 73 & $100 / \mathrm{mm}^{3}$ & $\begin{array}{l}\text { Median age, } 57.0 \text { y } \\
\text { with } 62 \% \text { men }\end{array}$ & NA & NA & $\begin{array}{l}294 \text { min } \\
\text { (median) }\end{array}$ \\
\hline $\begin{array}{l}\text { Andre et al, }{ }^{36} 2010 \\
47 \text { French hospitals } \\
\text { (France) }\end{array}$ & $\begin{array}{l}\text { Temp }>100.4^{\circ} \mathrm{F} \\
\text { WBC }<1000 / \mathrm{mm}^{3} \\
\text { or ANC }<500 / \mathrm{mm}^{3}\end{array}$ & $\begin{array}{l}198 \\
(89 \\
\text { with } \\
\text { sepsis } \\
\text { or } \\
\text { shock) }\end{array}$ & NA & $\begin{array}{l}\text { Mean age, } 61.0 y \\
\text { with } 61 \% \text { men }\end{array}$ & NA & NA & $\begin{array}{l}<90 \text { min } \\
\text { in } 19 / 89 \\
(21 \%) \\
\text { patients } \\
\text { with sepsis } \\
\text { or shock } \\
\text { received } \\
\text { antibiotics }\end{array}$ \\
\hline $\begin{array}{l}\text { Swajcer et al, }{ }^{37} 2011 \\
\text { Six hospitals of the } \\
\text { Winnipeg Regional } \\
\text { Health Authority } \\
\text { (Canada) }\end{array}$ & $\begin{array}{l}\text { Chemotherapy } \\
\text { Temp }>100.4^{\circ} \mathrm{F} \\
\text { ANC }<1500 / \mathrm{mm}^{3}\end{array}$ & 68 & $\begin{array}{l}230 / \mathrm{mm}^{3} \\
\text { (median) }\end{array}$ & $\begin{array}{l}\text { Median age, } 59.5 \text { y } \\
\text { with } 45 \% \text { men }\end{array}$ & NA & $\begin{array}{l}6 / 68 \\
(8.8 \%)\end{array}$ & $\begin{array}{l}300 \text { min } \\
\text { (median) }\end{array}$ \\
\hline $\begin{array}{l}\text { Sammut et al, }{ }^{38} 2012 \\
\text { Addenbrooke's hospital } \\
\text { (UK) }\end{array}$ & $\begin{array}{l}\text { Chemotherapy } \\
\text { Temp }>100.4^{\circ} \mathrm{F} \\
\text { ANC }<1000 / \mathrm{mm}^{3}\end{array}$ & 10 & NA & NA & NA & NA & $\begin{array}{l}154 \text { min } \\
\text { (median) }\end{array}$ \\
\hline $\begin{array}{l}\text { Perron et al, } 392014 \\
\text { Royal University } \\
\text { Hospital, University of } \\
\text { Saskatchewan } \\
\text { (Canada) }\end{array}$ & $\begin{array}{l}\text { Chemotherapy, } \\
\text { Temp }>100.4^{\circ} \mathrm{F} \\
\text { ANC }<500 / \mathrm{mm}^{3}\end{array}$ & 105 & $210 / \mathrm{mm}^{3}$ & $\begin{array}{l}\text { Median age, } 60.0 \text { y } \\
\text { with } 41 \% \text { men }\end{array}$ & NA & $\begin{array}{l}4 / 105 \\
(3.8 \%)\end{array}$ & $\begin{array}{l}150 \text { min } \\
\text { (median) }\end{array}$ \\
\hline
\end{tabular}

Abbreviations: ANC, absolute neutrophil count; ED, emergency department; NA, not available; temp, temperature.

convincing evidence of a positive clinical effect before it will be integrated into the care of patients. ${ }^{59,60}$

The authors believe that future guidelines and protocols recommending the rapid ( $<60$ minutes) initiation of antibiotic treatment for $\mathrm{FN}$ should be based on adequately powered and valid investigations that clearly indicate the effectiveness of this intervention. Only a few small studies have attempted to measure the effect of timing of initial antibiotic treatment in adult patients with neutropenia. Swajcer et $\mathrm{al}^{37}$ found no effect of antibiotic timing on 30-day mortality or length of hospital stay, but used only univariate analysis of 68 patients (with 6 deaths) and did not adjust for severity of illness or other potentially confounding factors to provide a valid measure of effect. Sammut and $\mathrm{Mazhar}^{38}$ assessed the effects of antibiotic timing using 22 oncology ward and 10 ED patients, and found a strong correlation between the door-to-antibiotic interval and inpatient 
length of stay $(R=0.84)$, and that patients received their initial dose of antibiotics faster when they presented to an oncology ward rather than the ED. Lynn et $\mathrm{al}^{61}$ found earlier administration of antibiotics to be associated with fewer serious complications (eg, unstable hemodynamic status, respiratory distress, altered mental status, newly developed arrhythmia, death) during hospitalization in a study of 78 patients with 81 episodes of FN presenting to the ED. And finally, Perron et $\mathrm{a}^{39}$ found delayed antibiotic administration to be associated with longer lengths of hospital stay but not mortality. Unfortunately, these studies were significantly underpowered and provided conflicting evidence of the effects of the timing of initial antibiotic treatment for adult patients presenting to the ED with FN. As a result, no evidencebased recommendations exist for the timing of ED antibiotic management of adult patients with FN.

Of particular note, in a recent study of 653 pediatric patients, Fletcher et $\mathrm{a}^{62}$ investigated the effects of time to antibiotic administration on $\mathrm{FN}$ in 3 patient care areas: the inpatient setting, ED, and outpatient clinical setting. ${ }^{62}$ The study included 1628 episodes of FN over an 8-year period and found that the delayed administration of initial empiric antibiotics was associated with a composite adverse event outcome score that included mortality, pediatric intensive care unit admission, and the need for intravenous fluid resuscitation. This study also found that the median time to antibiotics was 145 minutes in the ED versus 93 minutes in the outpatient clinical setting. In addition, the risk for an adverse event was $15.7 \%$ among pediatric patients with $\mathrm{FN}$ in the $\mathrm{ED}$ versus $6.5 \%$ among those in the outpatient clinical setting. Although these findings may not be directly generalizable to adult patients because of pathophysiologic differences between adults and children regarding sepsis, ${ }^{63}$ they provide additional information emphasizing the need for improved care of patients with cancer in ED settings.

The authors believe that larger and more definitive clinical investigations should be conducted to identify an optimal period for the initial administration of empiric antibiotics in adult patients with FN. If beneficial outcomes of earlier initial antibiotic treatment are illustrated, new administrative efforts will likely be developed to improve the ED care of patients with this severe, cancerrelated complication. Several small studies in different clinical settings have already indicated that administrative interventions can substantially reduce initial time to antibiotic treatment for pediatric and adult patients with FN. ${ }^{64-67}$ Effects of early versus delayed antibiotic treatment in various subgroups of patients with $\mathrm{FN}$ (based on demographic, clinical characteristics, type of underlying malignancy, degree of immune suppression, and prior allogeneic stem cell transplant) should also be estimated to address heterogeneous risks for death. In addition, future translational research should include assessments of administrative interventions aimed at reducing the time to initial empiric antibiotic treatment of FN in the ED setting, with decision-analytic studies to assess the cost-effectiveness of providing early versus delayed initial antibiotic treatment.

\section{References}

1. Burchenal, J.H. The historical development of cancer chemotherapy. Semin Oncol 1977;4:135-146.

2. Papac RJ. Origins of cancer therapy. Yale J Biol Med 2001;74:391-398.

3. Chabner BA, Roberts TG. Timeline: chemotherapy and the war on cancer. Nat Rev Cancer 2005;5:65-72.

4. Hirsch J. An anniversary for cancer chemotherapy. JAMA 2006;296:15181520.

5. Frei E, Levin RH, Bodey GP, et al. The nature and control of infections in patients with acute leukemia. Cancer Res 1965;25:1511-1515.

6. Bodey GP, Buckley M, Sathe YS, et al. Quantitative relationships between circulating leukocytes and infection in patients with acute leukemia. Ann Intern Med 1966;64:328-340.

7. Crawford J, Dale DC, Kuderer NM, et al. Risk and timing of neutropenic events in adult cancer patients receiving chemotherapy: the results of a prospective nationwide study of oncology practice. J Natl Compr Canc Netw 2008;6:109-118.

8. Raab SO, Hoeprich PD, Wintrobe MM, et al. The clinical significance of fever in acute leukemia. Blood1960;16:1609-1628.

9. Talcott JA, Finberg R, Mayer RJ, et al. The medical course of cancer patients with fever and neutropenia. Clinical identification of a low-risk subgroup at presentation. Arch Intern Med 1988;148:2561-2568.

10. Pizzo PA. Management of fever in patients with cancer and treatmentinduced neutropenia. New Engl J Med 1993;328:1323-1332.

11. Sipsas NV, Bodey GP, Kontoyiannis DP. Perspectives for the management of febrile neutropenic patients with cancer in the 21 st century. Cancer 2005;103:1103-1113

12. Ellis M. Febrile neutropenia. Ann NY Acad Sci 2008;1138:329-350.

13. Krell D, Jones AL. Impact of effective prevention and management of febrile neutropenia. Br J Cancer 2009;101:S23-26.

14. Lyman GH, Kuderer NM, Crawford J, et al. Predicting individual risk of neutropenic complications in patients receiving cancer chemotherapy. Cancer 2011;117:1917-1927.

15. Kuderer NM, Dale DC, Crawford J, et al. Mortality, morbidity, and cost associated with febrile neutropenia in adult cancer patients. Cance 2006; 106:2258-2266.

16. Schimpff S, Satterlee W, Young VM, et al. Empiric therapy with carbenicillin and gentamicin for febrile and gentamicin for febrile patient with cancer and granulocytopenia. N Engl J Med 1971;284:1061-1065.

17. Bodey GP, Ketchel SJ, Rodriguez V. A randomized study of carbenicillin plus cefamandole or tobramycin in the treatment of febrile episodes in cancer patients. Am J Med 1979;67:608-616.

18. Viscoli C. The evolution of the empirical management of fever and neutropenia in cancer patients. J Antimicrobl Chemother 1988;41(Suppl D):65-80.

19. Bodey GP. The changing face of febrile neutropenia-from monotherapy to moulds to mucositis. Fever and neutropenia: the early years. J Antimicrob Chemother 2009;63(Suppl 1):i3-13.

20. de Pauw B, Williams K, De Neeff J, et al. A prospective study of ceftazidime versus ceftazidime plus flucloxacillin in the empiric treatment of febrile episodes in severely neutropenic patients. Antimicrob Agents Chemother 1985;28:824-828.

21. Morrison VA. An overview of the management of infection and febrile neutropenia in patients with cancer. Supportive Cancer Ther 2005;2:88 94. 
22. Tam CS, O'Reilly M, Andresen D, et al. Use of empiric antimicrobial therapy in neutropenic fever. Intern Med J 2011;41:90-101.

23. Freifeld AG, Bow EJ, Sepkowitz KA, et al. Clinical practice guideline for the use of antimicrobial agents in neutropenic patients with cancer: 2010 update by the infectious diseases society of America. Clin Infect Dis 2011;52:e56-93.

24. Przybylo MA, Guleri A, Sharma R, et al. Febrile neutropenia: national guidelines are urgently needed. BMJ 2011;342:244-245.

25. National Chemotherapy Advisory Group. Chemotherapy services in England: ensuring quality and safety. Available at: http://webarchive. nationalarchives.gov.uk/20130107105354/http://www.dh.gov.uk/prod_ consum_dh/groups/dh_digitalassets/documents/digitalasset/dh_104501. pdf. Accessed May 12, 2012.

26. The Royal College of Radiologists. Clinical Oncology Information Network. Available at: http://www.rcr.ac.uk. Accessed May 12, 2012.

27. Marti F, Cullen MH, Roila F. Management of febrile neutropenia: ESMO clinical recommendations. Ann Oncol 2009;20(Suppl 4):166-169.

28. Penack $O$, Buchheidt $D$, Christopeit $M$, et al. Management of sepsis in neutropenic patients: guidelines from the infectious diseases working party of the German Society of Hematology and Oncology. Ann Oncol 2011;22:1019-1029.

29. Flowers CR, Seidenfeld J, Bow EJ, et al. Antimicrobial prophylaxis and outpatient management of fever and neutropenia in adults treated for malignancy: American Society of Clinical Oncology clinical practice guideline. J Clin Oncol 2013;31:794-810.

30. Baden LR, Bensinger W, Angarone M, et al. NCCN Clinical Practice Guidelines in Oncology: Prevention and Treatment of Cancer-Related Infections. Version 2.2014. Available at: NCCN.org. Accessed October $16,2014$.

31. Vandyk AD, Harrison MB, Macartney G, et al. Emergency department visits for symptoms experienced by oncology patients: a systematic review. Support Care Cancer 2012;20:1589-1599.

32. Perrone J, Hollander JE, Datner EM. Emergency department evaluation of patients with fever and chemotherapy-induced neutropenia. J Emerg Med 2004;24:115-119.

33. Nirenberg A, Mulhearn L, Lin S, et al. Emergency department waiting times for patients with cancer with febrile neutropenia: a pilot study. Oncol Nurs Forum 2004;31:711-715.

34. Courtney DM, Aldeen AZ, Gorman SM, et al. Cancer-associated neutropenic fever: clinical outcome and economic costs of emergency department care. Oncologist 2007;12:1019-1026.

35. Lim C, Bawden J, Wing A, et al. Febrile neutropenia in EDs: the role of an electronic clinical practice guideline. Am J Emerg Med 2012:30;5-11.

36. Andre S, Taboulet P, Elie C, et al. Febrile neutropenia in French emergency departments: results of a prospective multicentre survey. Crit Care 2010;14:R68.

37. Swajcer D, Czaykowski P, Turner D. Assessment and management of febrile neutropenia in emergency departments within a regional health authority: a benchmark analysis. Curr Oncol 2011;18:280-284

38. Sammut SJ, Mazhar D. Management of febrile neutropenia in an acute oncology service. QJM 2012;105:327-336.

39. Perron T, Emara M, Ahmed S. Time to antibiotics and outcomes in cancer patients with febrile neutropenia. BMC Health Serv Res 2014;14:162.

40. Pines JM. Timing of antibiotics for acute, severe infections. Emerg Med Clin North Am 2008;26:245-257.

41. Kumar A, Roberts D, Wood KE, et al. Duration of hypotension before initiation of effective antimicrobial therapy is the critical determinant of survival in human septic shock. Crit Care Med 2006:34:1589-1896.

42. Puskarich MA, Trzeciak S, Shapiro NI, et al. Association between timing of antibiotic administration and mortality from septic shock in patients treated with a quantitative resuscitation protocol. Crit Care Med 2011;39:2066-2071.

43. Aronin SI, Peduzzi P, Quagliarello VJ. Community-acquired bacterial meningitis: risk stratification for adverse clinical outcome and effect of antibiotic timing. Ann Intern Med 1998;129:862-869.

44. Miner JR, Heegaard W, Mapes A, et al. Presentation, time to antibiotics, and mortality of patients with bacterial meningitis at an urban county medical center. J Emerg Med 2001;21:387-392.

45. Proulx N, Frechette D, Toye B, et al. Delays in the administration of antibiotics are associated with mortality from adult acute bacterial meningitis. QJM 2005;98:291-298.

46. Strang JR, Pugh EJ. Meningococcal infections: reducing case fatality by giving penicillin before admission to hospital. Br Med J 1992;305:141-143.
47. McGarvey RN, Harper JJ. Pneumonia mortality reduction and quality improvement in a community hospital. QRB Qual Rev Bull 1993;19:124130.

48. Meehan TP, Fine MJ, Krumholz HM, et al. Quality of care, process, and outcomes in elderly patients with pneumonia. JAMA 1997;278:2080 2084.

49. Houck PM, Bratzler DW, Nsa W, et al. Timing of antibiotic administration and outcomes for Medicare patients hospitalized with community-acquired pneumonia. Arch Intern Med 2004;164:637-644.

50. Houck PM, MacLehose RF, Niederman MS, Lowery JK. Empiric antibiotic therapy and mortality among Medicare pneumonia inpatients in 10 western states: 1993, 1995, and 1997. Chest 2001;119:1420-1426.

51. Gleason PP, Meehan TP, Fine JM, et al. Associations between initial antimicrobial therapy and medical outcomes for hospitalized elderly patients with pneumonia. Arch Intern Med 1999;159:2562-2572.

52. Yealy DM, Auble TE, Stone RA, et al. Effect of increasing the intensity of implementing pneumonia guidelines: a randomized, controlled trial. Ann Intern Med 2005;143:881-894.

53. Natsch S, Kulberg BJ, Meis JF, et al. Earlier initiation of antibiotic treatment for severe infections after interventions to improve the organization and specific guidelines in the emergency department. Arch Intern Med 2000;160:1317-1320.

54. Lyman GH, Rolston KV. How we treat febrile neutropenia in patients receiving cancer chemotherapy. J Oncol Pract 2010;6:149-152.

55. Kollef $\mathrm{MH}$. Broad-spectrum antimicrobials and the treatment of serious bacterial infectious: getting it right up front. Clin Infect Dis 2008;47:S313.

56. Micek ST, Lloyd AE, Ritchie DJ, et al. Pseudomonas aeruginosa bloodstream infection: importance of appropriate initial antimicrobial treatment. Antimicrob Agents Chemother 2005;49:1306-1311.

57. Vallés J, Rello J, Ochagavía A, et al. Community-acquired bloodstream infection in critically ill adult patients: impact of shock and inappropriate antibiotic therapy on survival. Chest 2003;123:1615-1624.

58. Harbarth S, Garbino J, Pugin J, et al. Inappropriate initial antimicrobial therapy and its effect on survival in a clinical trial of immunomodulating therapy for severe sepsis. Am J Med 2003;115:529-535.

59. Larkin GL, Weber JE, Moskop JC. Resource utilization in the emergency department: the duty of stewardship. J Emerg Med 1998;16:499-503.

60. American College of Emergency Physicians. Resource utilization in the emergency department: the duty of stewardship. Available at: http://www. acep.org/Clinical-.-Practice-Management/Resource-Utilization-in-theEmergency-Department--The-Duty-of-Stewardship/. Accessed March 3, 2013.

61. Lynn JJ, Chen KF, Weng YM, Chiu TF. Risk factors associated with complications in patients with chemotherapy-induced febrile neutropenia in emergency department. Hematol Oncol 2013;31:189-196.

62. Fletcher M, Hodgkiss $\mathrm{H}$, Zhang $\mathrm{S}$, et al. Prompt administration of antibiotics is associated with improved outcomes in febrile neutropenia in children with cancer. Pediatr Blood Cancer 2013;60:1299-1306.

63. Aneja R, Carcillo J. Differences between adult and pediatric septic shock. Minerva Anestesiol 2011;77:986-992.

64. Baltic T, Schlosser E, Bedell MK. Neutropenic fever: one institution's quality improvement project to decrease time from patient arrival to initiation of antibiotic therapy. Clin J Oncol Nurs 2002;6:337-340.

65. Corey AL, Snyder S. Antibiotics in 30 minutes or less for febrile neutropenic patients: a quality control measure in a new hospital. J Pediatr Oncol Nurs 2008;25:208-212.

66. Best JT, Frith K, Anderson F, et al. Implementation of an evidencebased order set to impact initial antibiotic time intervals in adult febrile neutropenia. Oncol Nurs Forum 2011;38:661-668.

67. Amado VM, Vilela GP, Queiroz A Jr, Amaral AC. Effect of a quality improvement intervention to decrease delays in antibiotic delivery in pediatric febrile neutropenia: a pilot study. J Crit Care. 2011;26:103. e9-12. 